\title{
Profile of Implementation of Free Inquiry Learning Assisted By PhET and Critical Thinking Skills of Senior High School Students on Light Material
}

\author{
Anggi Aulidhia Rohmah, *Binar Kurnia Prahani \\ Physics Department, Faculty of Mathematics and Science, State University of Surabaya. Jl. \\ Ketintang, Surabaya, Jawa Timur 60231, Indonesia \\ *Corresponding Author e-mail: binarprahani@unesa.ac.id
}

Received: September 2021; Revised: October 2021; Published: December 2021

\begin{abstract}
This research was conducted to obtain a Free Inquiry Learning Implementation Profile assisted by PhET and Critical Thinking Skills of Senior High School Students on Light Material. The type of this research is descriptive preliminary research and does not test the hypothesis. The research subjects consisted of 111 students. Data collection techniques in a form of questionnaires, teacher interviews, and written tests which has been tested for validity and reliability. Then the data that has been obtained will be analyzed descriptively qualitatively. Based on the study results, findings in the form of 1) The ability of critical thinking skills of students in the low and medium category. The low category with a range of grades from 0 to 45 as many as 44 students where male 15 students, and 29 female students, the medium category with a range of grades from 46 to 75 as many as 63 students where male 4 students and 59 female students, and high category with a range 75 to 100 as many as 4 female students; 2) Criteria for the lowest critical thinking skills is "evaluation" with an average value of $1.00,3$ ) The implementation of the free inquiry model has the potential to improve student's critical thinking skills. It can be concluded if the critical thinking skills possessed by students are low, so it is necessary to increase student's critical thinking skills, namely by the implementation of free inquiry assisted by PhET.
\end{abstract}

Keywords: Critical Thinking Skill, Freee Inquiry, PhET

How to Cite: Rohmah, A., \& Prahani, B. (2021). Profile of Implementation of Free Inquiry Learning Assisted By PhET and Critical Thinking Skills of Senior High School Students on Light Material. Prisma Sains : Jurnal Pengkajian Ilmu dan Pembelajaran Matematika dan IPA IKIP Mataram, 9(2), 233-245. doi:https://doi.org/10.33394/j-ps.v9i2.4192

https://doi.org/10.33394/j-ps.v9i2.4192

Copyright $\odot$ 2021, Rohmah \& Prahani This is an open-access article under the CC-BY License. (c) (i)

\section{INTRODUCTION}

The obligation of the State of Indonesia in the shade of the education of its citizens is based on law No. 39 of 1999 on Human Rights Chapter 12 that Everyone has the right to protection for their personal development, for obtaining an education, self-prosperous, and improving to become a noble person, responsible, happy and prosperous after prosperity is a human right. Therefore, the Government of Indonesia held a mandatory 12-years learning program aimed at improving the quality of human resources to compete globally. For human resources to be able to develop and compete globally, the application of an education system that is not only a transfer of knowledge from teacher to student, but students are allowed to solve problems that require observation, search, experimentation, analysis, thinking and conclude independently to a concept or theory. The inquiry model has characteristics like a scientist. For example (1) students are involved with scientific questions, events, or phenomena; (2) students are accustomed to digging ideas, testing hypotheses, solving a problem and presenting observations; (3) students are involved in the analysis and achievement of data, and clarify the concepts previously described by the teacher; (4) 
students expand their new understanding and ability, and apply what has been learned to the new environment (5) students with the teacher reviewing what they have learned (NRC, 2000). Inquiry models that pressures students to find out independently is free inquiry. Free inquiry emphasizes learners learn independently, ranging from asking questions to finding solutions to a problem, so it is important to learners' independence (Putri et al., 201 5).

The free inquiry learning model is perfect for training students' high-level thinking skills. Observations show that the free inquiry and guided inquiry models are positively good for training high-level thinking skills (Zulfiani et al., 2017). Critical thinking skills can develop students' cognitive, emotional, and psychomotor abilities (Jufri, 2013). Critical thinking of students will affect learning outcomes. Students who think critically will be seen when analyzing problems to find solutions and determine the relationship with biological concepts. Critical thinking stimulates each student's cognitive structure to capture ideas and concepts and organize their knowledge to improve student's thinkingskills and thinking readiness. (Ajwar, 2015). Critical thinking skills include six aspects, namely (1) interpretation, namely the ability to understand and interpret data or information, (2) analysis is the ability to define relationships based on information used to convey or express opinions, (3) inference is the ability to identify and select the elements necessary to make reasonable conclusions, form values and hypotheses to consider relevant information and develop as a result of data or evidence, (4) explanation is the ability of students to explain or express statements or opinions based on evidence, methodology, and concepts, (5) Evaluation is the ability to test the truth, the ability to evaluate statements or opinions received by yourself and others, and (6) self-regulation is the ability to regulate one's existence when dealing with problems (Junaidi et al., 2018).

The industrial revolution 4.0 marked by the use of the Internet of Things (IoT) gave rise to a variety of products produced that can certainly facilitate human activities. Education is no exception. Many emerging new technologies as a support for learning for example virtual laboratory applications commonly called PhET. Simulation Physics Education Technology $(\mathrm{PhET})$ is an interactive network simulation using java and flash programming languages, developed by the University of Colorado team. PhET has developed many interactive simulations that are very useful for integrating computer technology (Perkins et al., 2006). PhET simulation has several advantages. Some of the advantages of PhET simulation are: 1) requiring engagement and interaction with students, 2) dynamic feedback, 3) educating students to have a constructivism mindset, 4) creating an interesting learning environment, because students can learn through learning sambal simulation, 5) can visualize the concept of physics (Perdana, 2017).

With the use of PhET as a media to support learning, it is very helpful for students to understand abstract physics concepts. For example, light is one of the basic concepts in physics. Students need to study refraction concepts correctly to understand advanced physics concepts such as light interference and light spectrum. However, students often experience misunderstandings about the concept of refraction (Kroothkaew \& Srisawasdi, 2014). Even still found students cannot distinguish refraction and reflection, do not understand the direction of light encroachment, and how refraction occurs on the surface of the medium (Kaekwong et al., 2010). In addition, students also assume that the speed of light is not related to the medium (Djanettea \& Fouad, 2014). Through PhET it is expected and allows visualizing the refraction of light when passing through two different mediums so that misconceptions in students can be reduced.

Based on study literature, no research specifically addresses the profile of implementation of free inquiry learning assisted by PhET and critical thinking skills of Senior High School. Therefore, this study will focus on obtaining truthful information from the profile of implementation of free inquiry learning assisted by PhET and critical thinking skills of Senior High School, specifically in physics learning on light material. The novelty of this research is to bridge the results of previous research and to obtain findings and 
recommendations related to the profile of students' physics critical thinking skills and the implementation of inquiry free learning assisted by PhET of Senior High School. Whether in school students are taught using a free inquiry learning model assisted by PhET simulation or not and how the level of critical thinking skills of students.

\section{METHOD}

This study was conducted on 111 students of grade XI MIPA MAN 2 Gresik in March 2021 consisting of 92 female students and 19 male students. This study uses a descriptive research design and does not test hypotheses. The study results are used to find out the right learning model that will be used to improve critical thinking skills. To obtain the data, the instrument used is (1) a teacher interview sheet containing an overview of the teacher in the classroom, (2) a test questionnaire containing twelve questions with four critical thinking indicators including interpretation, analysis, inference, and evaluation (Ennis, 1996), and (3) student questionnaire sheets through a google form. The data analysis technique that will be used in this research is descriptive qualitative analysis. The analysis is used because the researcher wants to describe the actual facts and situations.

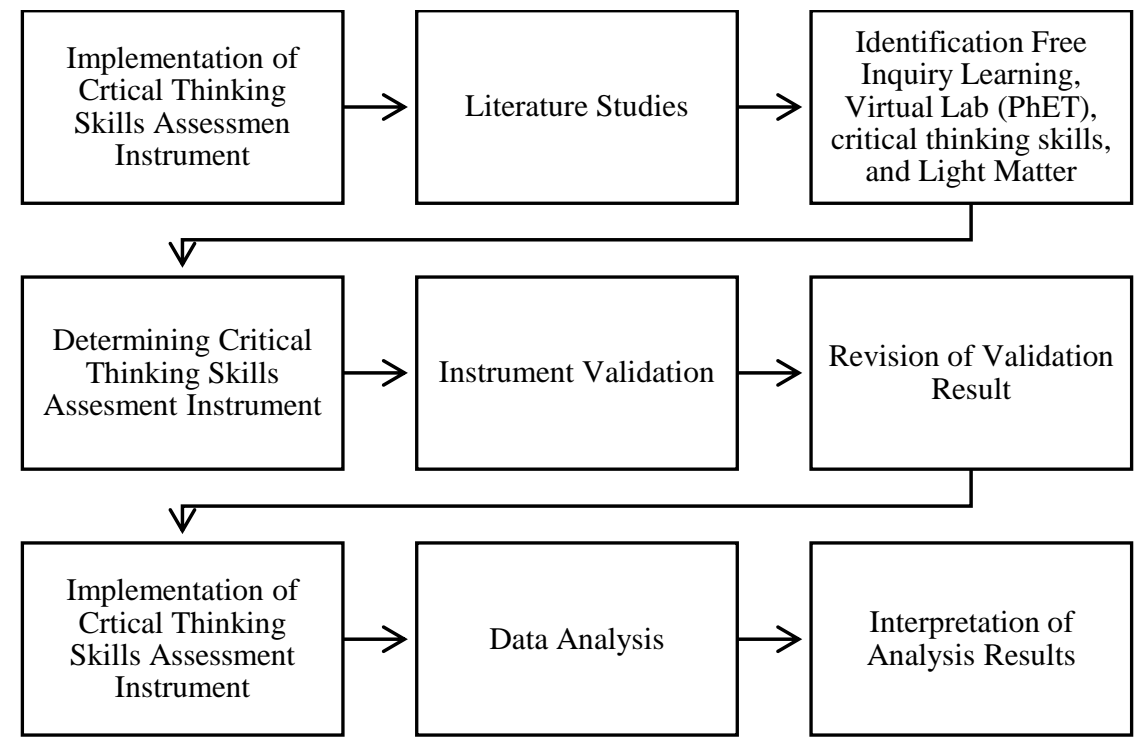

Figure 1. Research flowchart.

This study aims to know the profile of students' critical thinking skills, especially light material. The student test sheet consists of 12 essay questions from 4 indicators, namely interpretation, analysis, inference, and evaluation where each indicator consists of 3 questions. The student test sheet in the form of an essay was chosen because it can encourage students to present answers rather than just choose an answer (Zubaidah et al., 2015).

In conducting a study, an instrument is needed to measure something observed (Sugyono, 2010). To determine the quality of the test instrument, the instrument must be tested for validity and reliability. Validity is a measure that indicates the degree of validity of an instrument (Arikunto, 2013). How to measure validity is to use pearson product moment correlation. If the Pearson Product Moment correlation in each question is $r_{\text {count }}>r_{\text {table }}$ with $\alpha=0.05$ so the question is valid, and otherwise if $r_{\text {count }}<r_{\text {table }}$ so the measuring instrument is invalid. The validity test was conducted using the IBM SPSS Statistic application and obtained the following results (Table 1). 
Table 1. Validity Test Result

\begin{tabular}{ccccc}
\hline Question to- & $\mathbf{r}_{\text {table }}$ & $\mathbf{r}_{\text {count }}$ & Sig. & Description \\
\hline 1 & & 0.763 & 0.000 & Valid \\
2 & & 0.613 & 0.000 & Valid \\
3 & & 0.427 & 0.000 & Valid \\
4 & & 0.488 & 0.000 & Valid \\
5 & & 0.299 & 0.008 & Valid \\
6 & 0.176 & 0.434 & 0.000 & Valid \\
7 & & 0.684 & 0.000 & Valid \\
8 & & 0.598 & 0.000 & Valid \\
9 & 0.811 & 0.000 & Valid \\
10 & 0.294 & 0.002 & Valid \\
11 & 0.584 & 0.000 & Valid \\
12 & & 0.647 & 0.000 & Valid \\
\hline
\end{tabular}

Based on the Table 1 above, obtained $r_{\text {count }}>r_{\text {table }}$ means that the instrument used is valid. While reliability is a tool to measure a questionnaire that is an indicator of variables (Ghozali, 2013). A questionnaire is reliable if a person's answer to a statement is consistent or stable over time. The method used to test the realiability of questionnaires in this study is the Alpha Cronbach statistical test, where the Alpha Cronbach coefficient value of each research variable must be $\geq 0.6$ in order to be declared reliable. Here are the reliability test results using IBM SPSS Statistics.

Table 2. Reliability Statistics

\begin{tabular}{ll}
\hline Cronbach's Alpha & N of item \\
\hline .789 & 12
\end{tabular}

Based on the Table 1 above, each question of the above research variable is declared reliable because each variable has a Cronbach Coefficient value of alpha $\geq 0.6$.

Moreover, students were also given a questionnaire consisting of 10 questions about the student's experience while studying Physics at school. The level of critical thinking skills is calculated based on the respondent's answer. If the answer is logical, complete, and systematic will earn 5 points; if the answer only meets two elements (logical and complete or logical and systematic), the value is 3 ; if the answer only meets one element, then only gets a value of 1; and if the wrong answer gets a value of 0 . So the maximum point is 60 . Then to determine the value is done in the following way:

by category:

$$
\text { Final Value }=\frac{\text { Points earned }}{\text { Maximum Points }} \times 100
$$

High : if $75<$ score $\leq 100$

Medium : if $45<$ score $\leq 75$

Low : if score $\leq 45$

\section{RESULTS AND DISCUSSION}

\section{Students' Critical Thinking Ability in Light Materials}

Based on the evaluation with the above criteria, a critical thinking skill score varies between students is obtained. To determine the level of critical thinking skills, students are conducted by testing questions with critical thinking aspects such as interpretation, analysis, inference, and evaluation. 
1. Interpretation

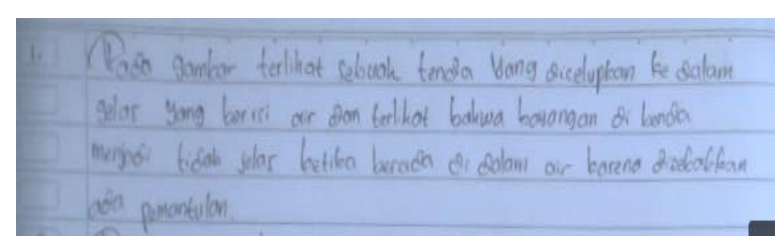

The picture shows an object that is dipped in a glass filled with water, and it can be seen that the image of the object becomes unclear when it is in the water due to reflection.

Figure 2. Student answers on interpretation indicators

In Figure 2, students are asked to understand and re-explain the events of a spoon that looks bent inside a glass. However, from the answer, students have not been entirely correct in interpreting it because what causes the spoon to look crooked when watered is the refraction of light instead of reflection.

2. Argument Analysis

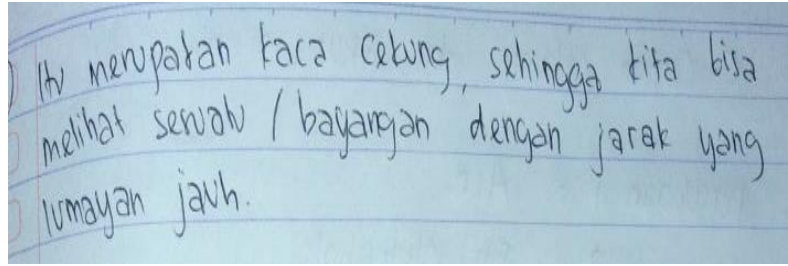

It's a concave mirror, so we can see things/images from quite a distance away

Figure 3. Student answers on analysis indicators

In the Figure 3, students are asked to analyze the shape of the shadow on the convex mirror placed across the street. Judging from the student's answer above, the correct answer is a convex mirror with a virtual shadow shape, upright, and minimized.

3. Inference

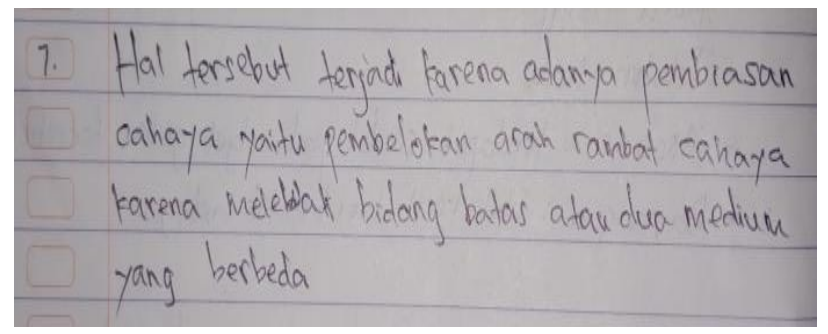

That happens because of the refraction of light, which is the bending of the direction of light propagation because it passes through two different mediums

Figure 4. Student answers on inference indicators

In the Figure 4, students are asked to identify to form a hypothesis of the pencil inserted into the glass. From the answer, the student only explained about the light-light distribution in general has not reached until the Snellius law.

4. Evaluation

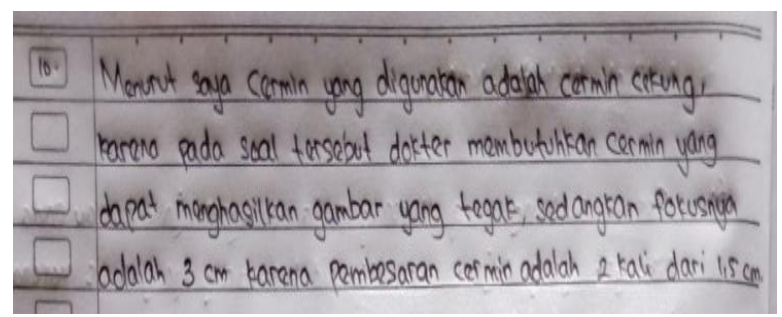

I think the mirror used is a concave mirror, because in this question the doctor needs a mirror that can produce an upright image, while the focus is $3 \mathrm{~cm}$ because the magnification of the mirror is 2 times of $1.5 \mathrm{~cm}$. 
Figure 5. Student answers on evaluation indicators

In Figure 5 students are asked to evaluate what type of mirror the dentist wears and its focus. But the student's answer is only true on the type of mirror. Most of them determining the focus directly using equations whereas the right thing is to look for the magnification first. Like the following $\frac{1}{f}=\frac{1}{s}+\frac{1}{s^{\prime}}$

To determine the distance of the shadow can be calculated through the equation

$$
\begin{gathered}
M=\frac{s^{\prime}}{s} \\
2=\frac{s^{\prime}}{1,5} \\
s^{\prime}=3
\end{gathered}
$$

Determine the focus distance of the mirror

$$
\begin{gathered}
\frac{1}{f}=\frac{1}{s}+\frac{1}{s^{\prime}} \\
\frac{1}{f}=\frac{1}{1,5}+\frac{1}{3}=\frac{2+1}{3}=\frac{3}{3}=1 \mathrm{~cm}
\end{gathered}
$$

From the four indicators above obtained the average on each indicator as follows (Figure 6).

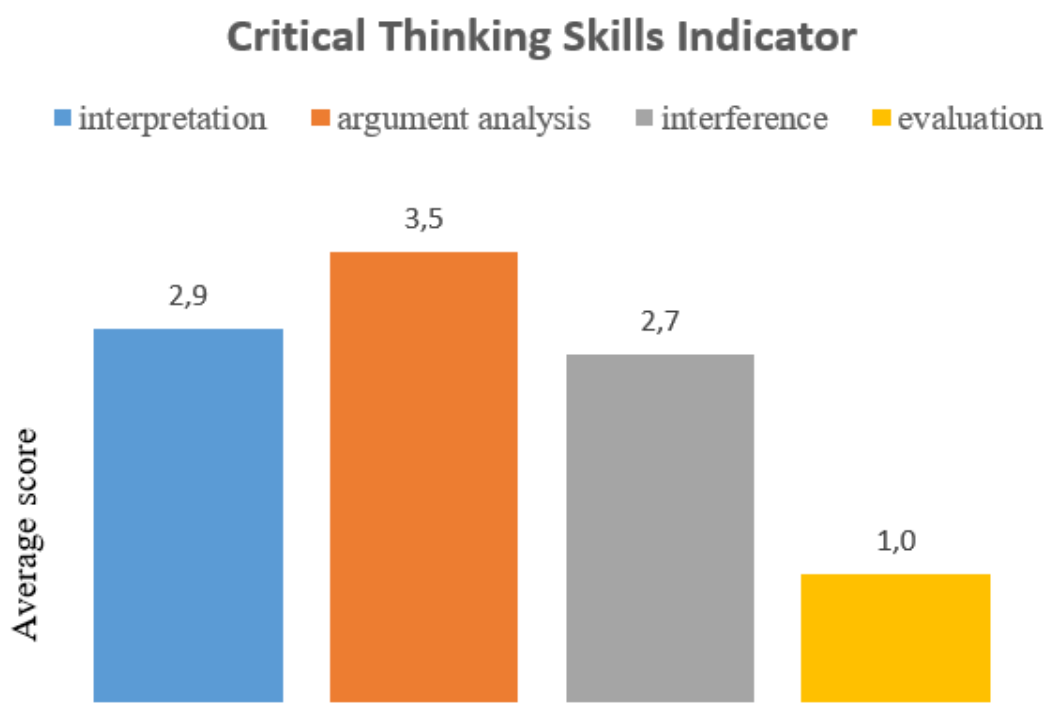

Figure 6. The result of the average value based on critical thinking skills indicators.

Based on the Figure 6, the lowest value of the critical thinking indicator is evaluation. Students' ability to evaluate problems is still relatively low, this may be because students still do not understand the equations in this material. In contrast, the highest indicator is the analysis of arguments. In all, of the 111 students, 44 were in the low category, 63 were moderately categorized, and 4 were in the high category. 


\section{Graph of Relation between Number of Student and Grade Category}

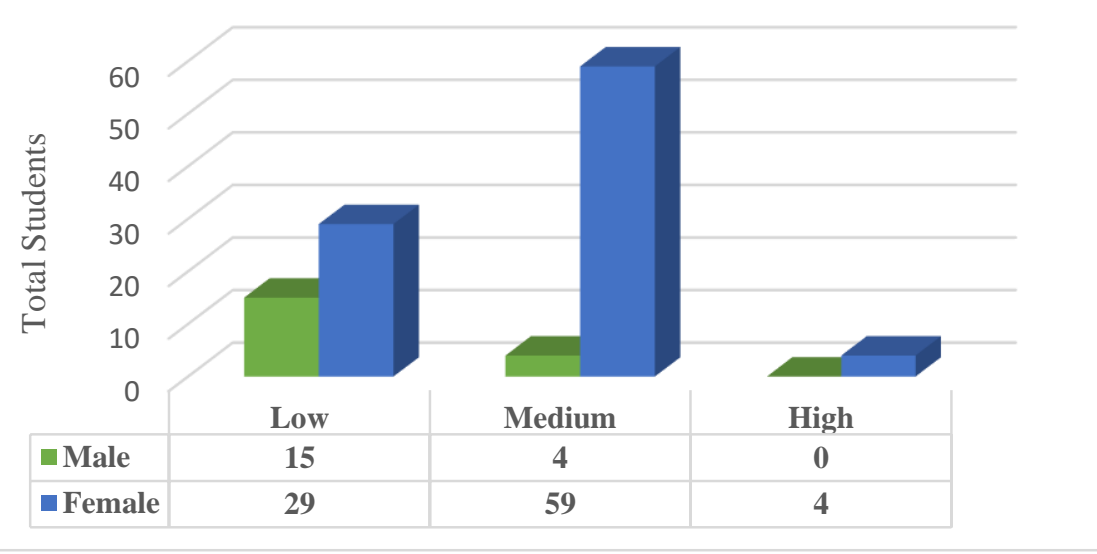

Figure 7. Student Critical Thinking Skills Category

From the 44 students with low category, 29 of them are female and the remaining 15 are male. In the medium category, 63 students consisting of 59 women and 4 men. And for the high category only owned by 4 female students.

\section{Critical Thinking Skills Students reviewed from Gender}

Based on Figure 7. Of the 111 students, 92 of whom are female students and 19 male students, female students' average critical thinking skills are higher than male students. This is in line with the research of Abdurrahman, Ahmad Yani, and Muhammad Tawil that after treatment model of computer-based intruction (CBI), critical thinking ability of female students is better than male students, 34.39 for female students and 30.48 male students.

\section{Student Questionnaire Results}

After working on critical thinking questions, 111 students of grade XI MIPA MAN 2 Gresik were asked to fill out questionnaires related to critical thinking skills with a total of 10 questions in Table 3.

Table 3. Student questionnaires on critical thinking skills.

\begin{tabular}{lcc}
\hline Question & Yes (\%) & No (\%) \\
\hline $\begin{array}{l}\text { Do you like physics? } \\
\text { Do you think the light-matter is important to understand? }\end{array}$ & 61.2 & 38.7 \\
$\begin{array}{l}\text { Do you find the light matter difficult to understand? } \\
\begin{array}{l}\text { Do teachers often use the lecture methods compared to } \\
\text { experimental-based learning in the laboratory in physics learning? }\end{array}\end{array}$ & 43.2 & 56.8 \\
$\begin{array}{l}\text { Have you ever conducted learning activities to increase critical } \\
\text { thinking skills? }\end{array}$ & 64 & 36 \\
$\begin{array}{l}\text { Have you ever been trained with critical thinking skills test } \\
\text { questions? }\end{array}$ & 73 & 27 \\
$\begin{array}{l}\text { Do you have difficulty when it comes to answering the critical } \\
\text { thinking skills test questions? }\end{array}$ & 72 & 28 \\
$\begin{array}{l}\text { Do you like methods used by teachers in physics learning? } \\
\text { Do you like online learning during the covid-19 pandemic? }\end{array}$ & 86.5 & 13.5 \\
Has the teacher trained you to use a PhET in Physics Learning? & 11.7 & 88.3 \\
\hline
\end{tabular}

In Table 3, students' responses to critical thinking skills show that most students like physics lessons and think light material is important to learn even though some students have 
difficulty learning. Most students say that teachers often use lecture methods in teaching and rarely do activities in the laboratory especially when the pandemic takes place. Most students have learned and trained in questions to improve critical thinking skills. However, there are still many of them who have difficulty when faced with critical thinking. Almost all students like the lecture method used by teachers during the learning. Most students do not like learning during the pandemic. And most students have never experimented with a virtual laboratory because they have never trained teachers using PhET. Therefore, it is important for teachers to look for alternatives to improve the critical thinking skills of their students.

\section{Interview with Teacher}

After interviewing physics teacher of grade XI MAN 2 Gresik, teachers often practice critical thinking skills in students through cooperative learning models and scientific approaches. But when students are faced with critical thinking questions, students still find it difficult to work on them. Because critical thinking is more difficult because students are asked to think complexly so the most important thing for physics teachers is how to understand students to understand the material well. Teachers use cooperative learning models, Teams Game Tournament (TGT), and Problem Based Learning (PBL) more often depending on the materials taught. Of all the models used, TGT got the best response because students are interested in the existence of games.

Teachers very rarely use inquiry learning models because they are considered ineffective in learning. Inquiry learning emphasizes students to be more active in seeking their information, while students tend to be passive when conducted inquiry learning. Teachers often invite students to conduct experiments in the laboratory. However, teachers have never conducted live trials or online experiments because teachers have never used PhET. Nevertheless, teachers still try to provide practical physics materials by providing practicum videos through the Youtube platform. The teacher will be devoted to learning Phetassisted Free Inquiry to improve students' critical thinking skills.

Based on the students' answers, there are still many students who are not right in answering critical thinking questions given. Both from interpretation indicators, analysis, inference, and evaluation. It is therefore important to continuously improve students' critical thinking skills. As Liliasari (2001), critical thinking skills are one of the most important aspects for everyone and are an essential part of human adult hood. Every human being has the potential to develop and think critically because it relates to the model of selfmanagement (self organization) of the existence of the person himself. Jufri (2013) also said that critical thinking skills can develop students' cognitive, emotional, and psychomotor aspects. In light material there are still many students who misconceptions. Students often misunderstandings about the concept of refraction (Kroothkaew \& Srisawasdi, 2014). Even still found students cannot distinguish refraction and reflection, do not understand the direction of light encroachment, and refraction that occurs on the surface of the medium (Kaekwong et al., 2010). In addition, students also assume that the speed of light is not related to the medium (Djanettea \& Fouad, 2014). Free inquiry learning is expected to help students improve students' critical thinking skills (Fuad et al., 2017). But this is different from the facts in the field. As the physics teacher said that the sequencing learning model is considered less effective in learning because it requires students to be more active in seeking their information.

The number of misconceptions experienced by students in light material is due to the abstraction of light material because it cannot be observed directly. Students cannot illustrate the light properly so virtual laboratory assistance is urgently needed in this regard. According to their field of study, Java program-based PhET stimulation was developed to make it easier for teachers to stimulate physics using computers (Sunni et al., 2014). This PhET can help overcome student misconceptions about abstract physics material. This is in line with afifah et al's research (2014) students' high-level thinking ability in guided inquiry 
learning rocky $\mathrm{PhET}$ on kinetic gas theory material is better than regular learning, so that the attitude of student responsibility can be improved. And Zahara's research (2014) showed that learning using PhET simulation is better than conventional learning because it can improve students' learning outcomes on the concept of static fluids. With the help of PhET simulation in inquiry learning, it is expected to help students understand the material more deeply and improve their critical thinking skills. To assess the effectiveness of PhET-assisted learning models on students' critical thinking skills based on previous research included in the systematic review can be seen in Table 4.

Table 4. Review of 2013-2021 studies.

\begin{tabular}{llll}
\hline \multicolumn{1}{c}{ Author (year) } & \multicolumn{1}{c}{ Research Tittle } & & \multicolumn{1}{c}{ Finding } \\
\hline Anggareni, N. & Implementation of & $\bullet$ & This research is experimental design \\
W., Ristiati, N. & Inquiry Learning & - & The data collected through pre-test and post-test \\
P., Widiyanti, & Strategy on Critical & - & This research shows differences in critical \\
N. L. P. M. & Thinking Ability and & & thinking skills and concept understanding \\
(2013) & Understanding of & & between students with inquiry learning \\
& Science Concepts for & & models compared to direct instructions.
\end{tabular}

Syarifah L. F., Students

A. Halim., Ibnu Khaldun (2016)

E. M. E. Putri., I. Kroto., D. H. Putri. (2018)

M. Eristya., N.
Aznam (2019)

Abdurrahman., A. Yani., M. Tawil (2019)
The use of PhET Simulation Media with a Guided Inquiry Approach to Improve Students' Critical Thinking Skills on the Subject of Heat at SMAN 12 Banda Aceh

Improving Science Process Skills and Mastery of Light Wave Concepts by Applying Inquiry Models Assisted by PhET Simulation XIMIPA SMAN 2 Bengkulu

Natural Science Learning with Modified Free Inquiry to Develop Students' Creative Thinking Skills

The Effect of PheT Simulation Virtual Learning in terms of Gender on Critical Thinking Skills for Class XI Students of SMA N 2 Makassar
- This research is experimental design.

- The data collection through pretest and posttest.

- The results indicate an influence and improvement after using PhET simulation through a guided inquiry approach to critical thinking skills by $76 \%$, seen from each indicator and item of critical thinking skills with a learning process of $4 \mathrm{x}$ treatment.

- This research is Classroom Action Research

- The result of this research that learning by apllying the Inquiry model assisted by PhET simulation can improve science process skills and mastery of light waves.

- The research using literature review method.

- The result of this research is learning with the modified free inquiry approach that can work well will develop students' creative thinking skills.

- This research is experimental design with treatment design by level $2 \times 2$.

- This research is to find out the influence of PhET simulation-assisted learning reviewed from gender on critical thinking skills.

- The result indicate that the critical thinking skills of female gender are higher than 


\begin{tabular}{ll}
\hline Author (year) & \multicolumn{1}{c}{ Research Tittle } \\
& \\
Maryam, & Effects of Inquiry \\
Kusmiyati, & Learning Model on \\
I Wayan Merta, & Students' Critical \\
\& I Putu & Thinking Skills \\
Artayasa &
\end{tabular}

(2020)

Kurnia A., Hairunisyah A., I Wayan $\mathrm{G}$. (2020)

\section{The Effect of Guided Inquiry Learning Model \\ PheT Media Assisted on Solving Ability Physics Problems and Critical Thinking for High School Students}

\section{B. K. Prahani.,}

E. Susiawati., U.

A. Deta., N. A. Lestari., M. N. R. Jauhariyah., M. A.

Mahdiannur, E. Candrawati, Misbah, S.

Mahtari,

Suyidno, J.

Siswanto,. (2020).

\section{Profile of Students'} Solving Skills and the Implementation of Inquiry (Free, Guided, and Structured) Learning in Senior High School
Physics Problem-
Faiz, H., Prastowo, T., Jatmiko, B., (2020)
The Use of Android-

Based PhET

Simulation as an

Effort to Improve

Students' Critical

Thinking Skills

during the Covid-19

Pandemic

\section{Finding}

male students when compared to the average.

- This research is experimental design.

- The data collection through test instruments is then analyzed with anakova test.

- The results indicated that there is a difference in critical thinking skills between experimental class students and control class students.

- The inquiry learning model affects students critical thinking skills.

- This research is experimental design.

- The data collections through pretest and posttest.

- The result of this research is indicate that PhET media-assisted inquiry learning model has an effect on improving problem solving skills and critical thinking physics

- This research using descriptive research design.

- The data collected by tests, questionnaire, and interviews.

- The result of this research is the students physics problem solving skills based on ACCES is still low.

- The implementation of inquiry (structured, guided, and free) in physics learning has not been maximally implemented to improve physics problem-solving skills in high schools;

- The use of virtual labs to support inquiry learning in the form of PhET has not been maximized;

- Inquiry learning cannot be maximized if students and teachers are not supported by real and virtual laboratories.

- This research is experimental design by using descriptive research

- The result of this research is the Science learning assisted by PhET can improve students' critical thinking skills. The highest indicator is "interpretation" and lowest is "analysis"

\section{CONCLUSION}

Based on the data analysis conducted, this study conclude that critical thinking ability of MAN 2 Gresik students is mostly in the low and medium category. The highest critical 
thinking indicator is "argument analysis" and the lowest indicator is "evaluation". From gender mapping, the average critical thinking skills of female students were higher than male students. This study implies that the right learning methods can affect students' critical thinking skills. Therefore, innovations are needed that can improve students' critical thinking skills. For example, by implementing a learning model with the help of virtual lab simulation, namely the implementation of free inquiry assisted by PhET. Further research is expected to be conducted with more varied indicators and materials used not only light matter.

\section{RECOMMENDATION}

It is recommended for teachers to apply Free Inquiry assisted by PhET as an effort to improve students' critical thinking skills. Critical thinking skills are needed by students in the future, because these skills are included in the skills that must be mastered to face the industrial revolution 4.0. So that human existence cannot be replaced by machines, it is importa nt to have critical thinking skills for students.

\section{ACKNOWLEDGMENT}

The author's deepest gratitude goes to physics teacher and students of MAN 2 Gresik, and all parties who have provided guidance, support, and direction during the process of compiling this article.

\section{REFERENCES}

Abdurrahman., Yani, A., \& Tawil, M. (2019). Pengaruh Pembelajaran Virtual Simulasi PhET Ditinjau dari Gender Terhadap Keterampilan Berpikir Kritis Peserta Didik Kelas XI SMA N 2 Makassar. Diploma Thesis. Universitas Negeri Makassar.

Afifah, R.M.A. (2014). Pengaruh Pembelajaran Guided Inquiry Berbantuan PhET Terhadap Kemampuan Berfikir Tingkat Tinggi dan Tanggung Jawab Siswa Kelas XI IPA Pada Materi Teori Kinetik Gas. Jurnal Pendidikan Fisika, 1(3), 1-9 .

Ajredini, F., Gjevori, A., Izairi, N., Rasimi, K., \& Zajkov, O. (2019). PhET Simulations Vs Real Experiments For Better Understanding Electrical Resistance. Science \& Research, 3 (1), 35-41

Ajwar, M. (2015). Pengaruh Pembelajaran Inkuiri Terbimbing dan Inkuiri Bebas Termodifikasi Terhadap Prestasi Belajar Ditinjau Dari Berpikir Kritis dan Kedisiplinan Belajar Siswa Kelas X MIA SMA Negeri 8 Surakarta Tahun Pelajaran 2014/2015. Jurnal Inkuiri , 4 (3), 127-135.

Anggareni, N. W., Ristiati, N. P., and Widiyanti, N. L. P. M. (2013). Implementasi Strategi Pembelajaran Inkuiri Terhadap Kemampuan Berpikir Kritis dan Pemahaman Konsep IPA Siswa SMP Program Pascasarjana. Universitas Pendidikan Ganesha.

Dasilva, B. E., H. Kuswanto., Wilujeng, I., and Jumadi. (2019). SSP Development with a Scaffolding Approach Assisted by PhET Simulation on Light Refraction to Improve Students' Critical Thinking Skills and Achievement of Science Process Skills. In IOP Conf. Series: Journal of Physics: Conf. Series (pp.1-12).

Djanettea B and Fouad C. (2014). Determination of university students' misconception about light using concept maps in Social and Behavioran. Proc. Int. Conf. on Science 152. (pp. 582-589).

Facione, P. A. (2013). Critical Thinking: What It Is and Why It Counts. Insight Assessment, $1-27$.

Fithriani, S. L., Halim, A., \& Khaldun, I. (2015). Penggunaan Simulasi Phet dengan Pendekatan Inkuiri Terbimbing untuk Meningkatkan Keterampilan Berfikir Kritis Siswa pada Pokok Bahasan Kalor di SMA Negeri 12 Banda Aceh. Jurnal Pendidikan Sains Indonesia, 4 (2), 45-52. 
Fuad, N. M., Zubaidah, S., Mahanal, S., \& Suarsini, E. (2017). Improving Junior High Schools' Critical Thinking Skills Based on Test Three Different Models of Learning. International Journal of Instruction , 10 (1), 101-116.

Handriani, L.S., Harjono, A., \& Doyan, A. (2015). Pengaruh Model Pembelajaran Inkuiri Terstruktrur dengan Pendekatan Sainstifik terhadap Kemampuan Berpikir Kritis dan Hasil Belajar Fisika Siswa. Jurnal Pendidikan Fisika dan Teknologi, 1(3), 210-220.

Hasyim, F., Prastowo T., \& Jatmiko B. (2020). The Use of Android-Based PhET Simulation as an Effort to Improve Students' Critical Thinking Skills during the Covid-19 Pandemic. International Journal of Interactive Mobile Technologies, 14 (19), 31-41.

Junaidi, E., Hadisaputra, S., \& Al Idrus, S. W. (2018). Kajian Pelaksanaan Praktikum Kimia Di Sekolah Menengah Atas Di Kabupaten Lombok Barat Indonesia. Jurnal Pijar Mipa, 13(1), 24-31.

Kroothkaew S and Srisawasdi N. (2014). Supporting students' conceptual development of light refraction by simulation-based open inquiry with dual-situated learning model. Journal Computer Education 1 (1), 49- 79.

Kaekwong K, Alex M, Emarat N and Arayathanitkul K. (2010). Thai high-school students' misconceptions about and models of light refraction through a planar surface. Physics Education, 45 (5), 97-107.

Kurnia, A., Sahidu, H., \& Gunada I. W. (2020). Pengaruh Model Pembelajaran Inkuiri Terbimbing Berbantuan Media PheT Terhadap Kemampuan Pemecahan Masalah dan Berpikir Kritis Fisika Peserta Didik SMA. Jurnal Pendidikan Fisika dan Teknologi, 6 (1), 17-24

Liliasari. (2001). Model Pembelajaran IPA untuk Meningkatkan Ketrampilan Berpikir Tingkat Tinggi Calon Guru sebagai Kecenderungan Baru pada Era Globalisasi. Jurnal Pengajaran MIPA, 2 (1).

Maryam., Kusmiyati., Merta, I. W., \& Artayasa, I. P. (2020). Effects Of Inquiry Learning Model On Students' Critical Thinking Skills. Jurnal Pijar MIPA, 15 (3), 2016-213.

Meisaroh, S., Achmadi, H. R. and Prahani, B. K. (2020). Profile of Students Problem Solving Skills and Implementation Free Inquiry Model in Senior High School. Berkala Ilmiah Pendidikan Fisika, 8(2), 59

Nafrianti, N., Supardi, Z. A. I., and Erman. (2016). Pengembangan Perangkat Pembelajaran Inkuiri Terbimbing Berbantuan Phet Pada Materi Listrik Dinamis Untuk Meningkatkan Keterampilan Berpikir Kritis Siswa. Pendidikan Sains Pascasarjana. Universitas Negeri Surabaya.

Nyoman, S.I, Bagus, P.I.A and Bagus, J.I.S. (2014). Pengaruh Model Pembelajaran Inkuiri Terhadap Ketrampilan Berpikir Kritis Dan Kinerja Ilmiah Pada Pelajaran Biologi Kelas Xi IPA SMA Negeri 2 Amlapura. Pascasarjana. Universitas Pendidikan Ganesha Program Studi IPA.

Perdana, A., Siswoyo, \& Sunaryo. (2017). penegembangan Lembar Kerja Siswa Berbasis Discovery Learning Berbantuan PHET Interactive Simulations pada Materi Hukum Newton. Jurnal wahana Pendidikan Fisika, 2

Perkins, et al. (2006). PhET: Interactive Simulations for Teaching and Learning Physics. Journal The Physics Teacher.

Prahani, B. K. et al. (2021). Profile of Students Physics Problem-Solving Skills and the Implementation of Inquiry (Free, Guided, and Structured) Learning in Senior High School. In IOP Journal of Physics: Conference Series, 1747 (1).

Putri, A. M., Mahardika, I. K., \& Nuriman. (2012). Model Pembelajaran Free Inquiry (Inkuiri Bebas) Dalam Pembelajaran Multirepresentasi Fisika di MAN 2 Jember. Jurnal Pembelajaran Fisika, 1 (3), 324-327

Putri, E. M. E., Koto, I., \& Putri, D. H. H. (2018). Peningkatan Keterampilan Proses Sains dan Penguasaan Konsep Gelombang Cahaya dengan Penerapan Model Inkuiri 
Berbantuan Simulasi PhET di Kelas XI MIPA E SMAN 2 Kota Bengkulu. Jurnal Kumparan Fisika, 1 (2), 46-52.

Rahayu, E. (2011). Pembelajaran Sains Dengan Pendekatan Keterampilan Proses Untuk Meningkatkan Hasil Belajar Dan Kemampuan Berpikir Kreatif Siswa. Jurnal Pendidikan Fisika Indonesia, 1 (7), 106 - 110.

Saputra, T.B.R.E., Nur, M., \& Purnomo, T. (2017). Pengembangan Pembelajaran Inkuiri Berbantuan PhET untuk Melatihkan Keterampilan Proses Sains Siswa. Journal of Science Education and Pratice, 1(1), 20-31.

Sunni, M.A., Wartono, dan Diantoro, M. (2014). Pengaruh Pembelajaran Problem Solving Berbantuan PhET Terhadap Penguasaan Konsep Fisika dan Kemampuan Berpikir Kritis Siswa SMA. Pasca Sarjana MPIPA. Universitas Negeri Malang.

Sutama, I.N., Arnyana, I.B.P., \& Swasta, I.B.J. (2014). Pengaruh Model Pembelajaran Inkuiri Terhadap Keterampilan Berpikir Kritis dan Kinerja Ilmiah Pada Pelajaran Biologi Kelas XI IPA SMA Negeri 2 Amplapura. E-Journal Program Pascasarjana. Universitas Pendidikan Ganesha.

Yeritia, S., Wahyudi., \& Rahayu S. (2017). Pengaruh Model Pembelajaran Inkuiri Terbimbing Terhadap Penguasaan Konsep dan Kemampuan Berpikir Kritis Fisika Peserta Didik Kelas X SMAN 1 KuripanTahun Ajaran 2017/2018. Jurnal Pendidikan Fisika dan Teknologi, 3(1), 181-187. 